\title{
ŚMIERĆ PRZYWRÓCONA. LUDOBÓJSTWO W REPORTAŻACH WOJCIECHA TOCHMANA
}

\author{
MATEUSZ ZIMNOCH* \\ Żadna technika przedstawiania świata nie jest wieczna. \\ Wieczna jest tylko potrzeba unieśmiertelniania świata \\ poprzez utrwalenie tego, co nietrwałe ${ }^{1}$.
} Régis Debray

Wszechobecność śmierci w mediach nie tylko nie wywołuje większego zdziwienia, lecz zdaje się być czymś tak oczywistym, że na ogół niewartym głębszej refleksji. Postępujące osłabienie wrażliwości społecznej sprawia, iż temat śmierci rzadko kiedy wywołuje dziś w ludziach szok, a przeciętny odbiorca komunikatów medialnych nie reaguje już na wieść o setkach zmarłych, z dawnym przeję$\mathrm{ciem}^{2}$. Jest to skutek bezwzględnego niekiedy łamania tabu i mieszania porządku prywatnego z publicznym, w wyniku którego kolejne obszary życia ludzkiego włączane są w granice oficjalnego dyskursu, a rosnąca tolerancja odbiorców pozwala na percepcję coraz bardziej drastycznych obrazów.

Magdalena Hodalska, analizując programy telewizyjne pod kątem łamania kluczowych tematów tabu, zauważa, iż „telewizja jest narzędziem transmisji i dekonstrukcji tabu: przekazuje wiedzę o zakazach, a z drugiej strony sama te

* Mateusz Zimnoch - doktorant, Instytut Filozofii UJ.

${ }^{1}$ R. De br a y, Narodziny przez śmierć, przeł. M. Ochab [w:] red. S. Rosiek, Wymiary śmierci, Gdańsk 2010, s. 260.

${ }^{2}$ Najlepszym przykładem mogą być reakcje na komunikaty dotyczące statystyk wypadków drogowych. Wielu odbiorców na wieść o tym, że w danym okresie zginęła określona liczba osób, reaguje entuzjastycznie, zauważając, iż rok wcześniej ofiar było dwa razy więcej. Tym samym indywidualna śmierć zostaje sprowadzona wyłącznie do statystyki. O specyfice śmierci stanowi to właśnie, iż wywiera tym większe wrażenie, im bardziej jest jednostkowa. Pisał o tym Ryszard Kapuściński: „Paradoks śmierci: że najsilniejsze wrażenie wywołuje śmierć pojedyncza, wyodrębniona, zabierająca jednego człowieka, którego rysy możemy określić, a nazwisko wymienić. Im zwiększa się liczba ofiar śmierci, tym działanie jej na naszą wrażliwość słabnie. Duża liczba - zamiast potęgować wrażenie - zabija je" (R. Kapuścińs ki, Lapidaria, Warszawa 2008, s. 415-416). 
zakazy łamie"’3. To celne spostrzeżenie wskazuje na kluczową właściwość mediów masowych: ich samozwrotność. Idąc tropem badaczki, można stwierdzić, iż telewizja na swój sposób legitymizuje określony system normatywny po to tylko, by natychmiast go przekroczyć, wykorzystując go do swobodnego budowania własnego kapitału ekonomicznego. Można nawet pójść dalej i stwierdzić, że niejednokrotnie media same konstruują określone ramy instytucjonalne w celu ich późniejszego przekroczenia; kreując wśród odbiorców określone wyobrażenia dotyczące otaczającej ich rzeczywistości, jednocześnie te wyobrażenia rozbijają. Można chyba zaryzykować twierdzenie, iż podobnie jak reklama kreuje potrzeby po to, by następnie je zaspokajać, tak media masowe konstruują określony obraz świata po to, by go następnie podważać, rozbijać i przekraczać. Podobna teza pozostaje w zgodzie z twierdzeniem Hodalskiej, dotyczącym łamania tabu śmierci. Badaczka słusznie stwierdza:

Człowiek współczesny zna śmierć głównie z telewizji, która bardzo często zniekształca obrazy prawdziwego cierpienia. Przekaz medialny staje się narzędziem „oswajania” śmierci. Częste jej pokazywanie i widowiskowa forma sprawiają, że śmierć staje się niegroźna, obca i daleka ${ }^{4}$.

Wyraźny jest tu proces przejścia od kreacji określonego wyobrażenia śmierci (,zniekształca obrazy prawdziwego cierpienia”) oraz jej hiperbolizacji (,częste jej pokazywanie i widowiskowa forma") do oswojenia, będącego swoistą negacją sytuacji wyjściowej. Na problem ten zwraca uwagę L. V. Thomas, pisząc w swym fenomenalnym studium dotyczącym trupa:

Media chętnie wydają na pożarcie pozbawionym dramatów masom najbardziej sensacyjne obrazy trupów: straceni w Iraku lub Ugandzie, żołnierze w battle-dressach pokazujący triumfalnie jakąś głowę z Biafry lub Wietnamu, skrwawione zwłoki Aldo Moro lub dziennikarza podziurawionego kulami w Nikaragui [...]. Wstrząs powodowany tego rodzaju obrazami sprawia, że ucieka się do nich czasami reklama [...]. Pozbywanie się zmarłego przez wysługiwanie się nim na wszelkie sposoby dla zadowolenia wojeryzmu jest bez wątpienia ostatecznym sposobem negowania śmierci; banalizuje się ją, sprowadzając do kroniki wypadków, których powtarzalność rozładowuje tragizm $^{5}$.

Jak widać, wysoki poziom nasycenia mediów tematem śmierci oraz przesadna, przerysowana forma jej ukazywania paradoksalnie sprawiają, że realny problem umierania zostaje odsunięty od odbiorcy i zastąpiony sztucznym, świadomie konstruowanym substytutem. Tendencja, o której mowa, nie dotyczy wyłącznie mediów, jednakże te ostatnie działają w jej służbie. Substytucyjne nagromadzenie śmierci w środkach masowego przekazu współgra $\mathrm{z}$ równoległym procesem,

${ }^{3}$ M. Hod a ls k a, Łamanie tabu sacrum, śmierci i ciała $w$ programach telewizyjnych $w$ świetle skarg do KRRiT, ,Zeszyty Prasoznawcze” R. XLVII, nr 3-4/2004 (179-180), s. 87.

${ }^{4}$ Tamże, s. 92.

${ }^{5}$ L. V. Th o m as, Trup. Od biologii do antropologii, przeł. K. Kocjan, Łódź 1991, s. 108. 
o którym pisze Thomas; jej wypieraniem ze świadomości społecznej i przenoszeniem w świat fikcji ${ }^{6}$. Na opisywany problem po raz pierwszy zwrócił uwagę Max Scheler, dowodząc, iż człowiek współczesny nie tylko nie wierzy już w życie po śmierci, lecz przestał nawet wierzyć w samą śmierć. Pozbywając się stale towarzyszącego mu przekonania o własnej śmiertelności, sprowadził ją zaledwie do rangi sądu ${ }^{7}$. Koncepcja filozoficzna Schelera odcisnęła olbrzymie piętno na całej późniejszej myśli, co widoczne jest zwłaszcza u Adorna.

Trudno w tym miejscu szczegółowo referować poglądy kolejnych filozofów, zwłaszcza że prawdziwie nowoczesne badania nad problemem śmierci przynależą do francuskiej antropologii, która podziela zresztą ogólne przekonania Schelera, opatrując je przy tym mniej abstrakcyjną a bardziej empiryczną ramą. Philippe Ariés, formułując swoją koncepcję śmierci odwróconej, zauważa na przykład, iż weszliśmy w nowy etap rozwoju cywilizacyjnego, charakteryzujący się całkowitym odwróceniem zasad, jakimi wcześniej rządziły się relacje pomiędzy społeczeństwem a śmiercią:

Nawet najmniej spostrzegawczemu obserwatorowi rzucają się w oczy dwa fakty: jest to zupełna nowość, polegająca na przeciwstawianiu się wszystkiemu, co było poprzednio, na stworzeniu pewnego „odwróconego” obrazu, pewnego negatywu - społeczeństwo wyrzekło się śmierci, z wyjątkiem śmierci mężów stanu. W mieście nie ma już żadnych oznak, że coś się zdarzyło: dawny srebrzysto-czarny karawan stał się zwyczajną szarą limuzyną, trudną do rozpoznania w ulicznym ruchu. Społeczeństwo nie robi już żadnej przerwy: zniknięcie jakiejś jednostki nie wpływa ujemnie na jego ciągłość. Życie miasta toczy się takim rytmem, jakby nikt w ogóle nie umierał.

Znamiona tego odwrócenia, niespodziewanego i niezwykle szybkiego wykrystalizowania się swoistego kulturowego à rebours, dostrzega bardzo wielu antropologów śmierci. Maurice Abiven pisze na przykład:

Bardzo różne przyczyny złożyły się na to, że co najmniej od pół wieku nasze zachodnie społeczeństwo starało się jak najmniej wiedzieć o śmierci i o wszystkim, co ją otacza. Śmierć w domu, śmierć na co dzień, śmierć krewnego, bliskiego, sąsiada stawała się czymś coraz mniej znanym, coraz mniej widocznym, coraz bardziej zacieranym; potwierdza to coraz mniejsza liczba ceremonii

${ }^{6}$ Na zjawisko to wskazuje M. Vovelle, analizując współczesne tendencje literackie: „Wydaje mi się, że jedną z podstawowych cech, jakie w tej dziedzinie [literackich refleksji nad śmiercią przyp. M. Z.] ujawnia XX wiek, jest coraz wyrazistszy rozdźwięk między społecznym preudokonsensusem, jakim jest tabu śmierci - narzucającym konwencje tym surowsze, że niewypowiedziane - a obfitością, z jaką mówi się o niej w świecie marzeń i fantastyki. To być może naturalna kompensacja, wpisująca się w całościową dialektykę. Rzecz jasna, nietrudno byłoby znaleźć bezpośrednie czy wręcz dosłowne świadectwa milczenia, które zaległo nad światem śmierci” (M. Vovelle, Śmierć w cywilizacji Zachodu, przeł. T. Swoboda i in., Gdańsk 2004, s. 687).

${ }^{7} \mathrm{Na}$ ten temat zobacz w szczególności: G. S c he re r, Filozofia śmierci. Od Anaksymandra do Adorno, przeł. W. Szymona OP, Kraków 2008, s. 25-28.

${ }^{8}$ P. Arié s, Śmierć odwrócona, przeł. J. M. Godzimirski [w:] red. S. Cichowicz, J. M. Godzimirski, Antropologia śmierci. Myśl francuska, Warszawa 1993, s. 228. 
pogrzebowych i prawie całkowity zanik obrzędów żałobnych. W szczególności w szpitalach, gdzie ludzie coraz częściej umierają i gdzie śmierć jest zjawiskiem codziennym, panowała cicha zmowa, aby jej nie dostrzegać i postępować tak, jak gdyby nie istniała9.

Niektórzy wskazują nie tylko na przejawy społecznego odsuwania myśli o śmierci, ale wręcz na te ich aspekty, które czynią z niej obszar naznaczony znamionami wstrętu ${ }^{10}$. Michel Vovelle zauważa, że „uświadomiliśmy sobie całkiem niedawno, najpierw w Stanach Zjednoczonych i w atlantyckiej Europie, jakim tabu stała się śmierć w naszej epoce: ukryte w szpitalach zgony i zakaz żałoby uczyniły z niej nową kategorię obsceniczności”" ${ }^{11}$. Problem śmierci urasta tu niemalże do rangi estetycznej. Obszar sztuki nie jest zresztą pominięty w tego typu refleksji. A. Fabre-Luce podobnych zjawisk doszukuje się w relacjach pomiędzy pisarzem a jego czytelnikami:

Na ogół publiczność, gdy słyszy o śmierci, spodziewa się dwóch rzeczy: uniknięcia nudy za pomocą silnych wrażeń oraz powrotu na swój fotel typu „relaks” wskutek końcowego pocieszenia. Istnieje cicha umowa między pisarzem a społeczeństwem. Liczę na ciebie, mówi mu ono, że dostarczysz mi środków do wykorzystania, puszczenia w niepamięć, opóźnienia, zamaskowania lub przekroczenia śmierci. Po to ciebie zaangażowałem. Jeżeli zadania tego nie wykonasz, zostaniesz odprawiony (tzn. nie będziesz czytany) $)^{12}$.

Choć powyższe wypowiedzi nabierają już charakteru twierdzeń z pogranicza estetyki, należy zaznaczyć, iż ogólna idea ma silne podstawy antropologiczne. Dodatkowym dowodem na jej trafność może być fakt, iż podzielają ją nie tylko filozofowie i antropologowie, lecz także reprezentanci nauk przyrodniczych. Jacques Ruffié w swoim studium Seks $i$ śmierć pisze:

W nowoczesnych społeczeństwach uprzemysłowionych śmierć jest starannie ukrywana. Uważa się ją za katastrofę, za coś wstydliwego, co należy odsunąć jak najdalej, a kto wie, może i całkowicie zlikwidować, jeśli nauka znajdzie odpowiednie środki. Nadzieja ta jest absurdalna, ponieważ nawet jeżeli pewnego dnia możliwe będzie wyleczenie wszystkich chorób, nie da się powstrzymać procesu starzenia się i ,śmierci fizjologicznej”, które - jak widzieliśmy - stanowią część naszego programu genetycznego $i$, w ostatecznym rozrachunku, pozwalają na postęp w ewolucji ${ }^{13}$.

${ }^{9}$ M. Abiven, Accompagner la mort [w:] „Études”, novembre 1986, s. 465 (przekład za: S. Cichow ic z, Śmierć: gwałt na idei lub reakcja życia. Wstęp [w:] red. S. Cichowicz, J. M. Godzimirski, Antropologia..., s. 6).

${ }^{10}$ Problem związków pomiędzy śmiercią a wstrętem podejmuję w drugiej dygresji interpretacyjnej.

${ }_{11}$ M. Vovelle, Historia ludzi w zwierciadle śmierci, przeł. M. Ochab [w:] red. S. Rosiek, Wymiary..., s. 41.

12 A. Fabre-Luce, La mort a changé, Paris, Gallimard 1966, s. 12 (przekład za: L. V. Th o$\mathrm{m}$ as, Wprowadzenie do antropotanatologii, przeł. S. Cichowicz [w:] red. S. Cichowicz, J. M. Godzimirski, Antropologia..., s. 25).

13 J. Ru ffié, Seks i śmierć, przeł. B. A. Matusiak, Warszawa 1997, s. 295. 
Obserwacja dotycząca społecznego wypierania tematu śmierci podzielana jest przez bardzo wielu badaczy, co jest istotnym dowodem na jej trafność. Jeżeli przyjąć, iż rzeczywiście doszło do odwrócenia, o którym pisze Ariés, to uprawniona zdaje się zasugerowana na początku artykułu teza mówiąca, iż w s półcześnie temat śmierci jest świadomie przenoszony ze sfery życia społecznego do środków masowego przekazu,będących z jednej strony główną przestrzenią jej obecności, z drugiej - jednym z podstawowych narzędzi jej oswajania i oddalan i a. Jeśli uznać ten binarny, samozwrotny układ za obowiązujący - a wydaje się, że jest to uzasadnione - wówczas należy zaznaczyć, iż hipotetycznie najbardziej interesujące powinny być te komunikaty, które mu się wymykają. To właśnie one są centralnym obiektem zainteresowania niniejszego szkicu.

Z oczywistych względów nie sposób poddać analizie wszystkich gatunków komunikacji medialnej, które wykraczają poza nakreślony wyżej model, jednak bazując na stawianych już wcześniej tezach, można uznać, iż jednym z najciekawszych i najbardziej reprezentatywnych dla podejmowanej tu refleksji gatunków może być współczesny reportaż - gatunek niezwykle niejednoznaczny, rozwijający się wielokierunkowo oraz będący nosicielem tej cechy, która pozwala mu odbijać kluczowe problemy realiów zmediatyzowanej rzeczywistości, przy jednoczesnym sprzeciwie wobec tych realiów ${ }^{14}$. Dlatego materiałem badawczym dla poniższej analizy będą właśnie reportaże, z konieczności ograniczone do jednego tylko autora - Wojciecha Tochmana ${ }^{15}$. Osią refleksji warto uczynić dwie jego książki: Jakbyś kamień jadła oraz Dzisiaj narysujemy śmierć. Obydwie traktują o ludobójstwie, pokazując śmierć w szczególnym kontekście, pociągającym za sobą szerszą refleksję nad naturą ludzką, przemocą i złem. Jednak ten właśnie rodzaj śmierci wydaje się najciekawszy z punktu widzenia komunikacji - to, jak reportażysta radzi sobie z okrucieństwem, traumą, a niekiedy nawet odczuciem wstrętu, ewokuje niezwykle interesujące zjawiska, których antropologiczna interpretacja pozwala wskazać miejsce śmierci we współczesnym świecie.

\section{II}

Podstawową cechą, jaka narzuca się w trakcie lektury reportaży Tochmana, jest niemal każdorazowe ujmowanie śmierci nie tyle jako problemu samego

${ }^{14}$ Więcej na ten temat zob. [w:] M. Zi m n o ch, Fikcja jako prawda. Referencyjność reportażu ponowoczesnego, ,Naukowy Przegląd Dziennikarski” nr 1/2012.

${ }^{15}$ Na materiał badawczy składają się dwie książki, dla których śmierć jest tematem przewodnim: W. Toch man, Dzisiaj narysujemy śmierć, Wołowiec 2010; te goż, Jakbyś kamień jadła, Wołowiec 2008. Warto jednakże pamiętać o szerokiej obecności tematu śmierci w innych tekstach Tochmana, m.in.: W. Tochman, Amen [w:] te goż, Bóg zapłać, Wołowiec 2010, s. 195-215; t e g o ż, Mojżeszowy krzak [w:] te g o ż, Bóg..., s. 15-33; te g o ż, Wściekty pies [w:] te g o ż, Bóg..., s. $217-235$. 
umierającego, lecz tych, którzy pozostają przy życiu. Nastawienie to jest widoczne praktycznie na każdym kroku. Często sprowadza się do poziomu podstawowego, jakim jest pochówek zmarłego: „Przyjechali tu, żeby zobaczyć, znaleźć i pochować. Wydaje im się, że wtedy poczują ulgę, spokój”'16. Oczywiście można - i należy - interpretować powyższą potrzebę w kategoriach kulturowych. Edgar Morin zauważa, iż:

Nie istnieje praktycznie żadna grupa pierwotna, nawet najbardziej „,prymitywna”, która pozostawia zmarłych ich losowi, czy też czyni to bez obrzędów [...]. Etnologia ukazuje nam, że zmarli wszędzie byli lub są przedmiotem trosk, które odpowiadają wierze w ich życie pośmiertne (w formie widm, duchów, zjaw itp.) lub w ich odrodzenie ${ }^{17}$.

\section{Régis Debray uznaje wręcz pochówek za warunek zaistnienia cywilizacji:}

Każda cywilizacja traktuje śmierć po swojemu i swoim stosunkiem do śmierci różni się od innych; każda ma swoje własne formy pochówku, a nie byłaby cywilizacją, gdyby w ogóle nie zajmowała się grobem (upadek architektury żałobnej w czasach współczesnych zbliża nas do stanu barbarzyństwa $)^{18}$.

Podobne spostrzeżenia pojawiają się m.in. u Louisa Vincenta-Thomasa ${ }^{19}$, Ulricha Manna ${ }^{20}$ czy Jacquesa Ruffiée ${ }^{21}$, choć niektórzy spośród współczesnych badaczy zaczynają je dziś negować22. Niezależnie od tego w tekstach Tochmana

${ }^{16}$ W. Toch ma n, Jabkyś..., s. 12.

17 E. Mor i n, Antropologia śmierci, przeł. S. Cichowicz, J. M. Godzimirski [w:] red. S. Cichowicz, J. M. Godzimirski, Antropologia..., s. 79.

18 R. Debray, dz. cyt., s. 248.

${ }^{19}$ L. V. Th om as, Wprowadzenie do antropotanatologii, przeł. S. Cichowicz [w:] red. S. Cichowicz, J. M. Godzimirski, Antropologia..., s. 29.

20 „Najbardziej miarodajnym wykopaliskiem z najdawniejszych czasów są pozostałości związane z pogrzebem; w każdym razie one właśnie jednoznacznie wskazują na uprzedni proces hominizacji. Tutaj więc najwyraźniej dostrzegamy różnicę pomiędzy człowiekiem i zwierzęciem [...] sam odpowiednio ręcznie obrobiony krzemień [...] mógłby pochodzić także od małpiątek", U. M a n n, Der Tod in der religiösen Vorstellungswelt der Zeiten und Kulturkreise [w:] red. A. Paus, Grenzerfahrung Tod, Graz-Wien-Köln 1976, s. 110-114 (tłum. za: G. S c h e re r, dz. cyt., s. 42).

${ }^{21}$ „Wszystkie zwyczaje pogrzebowe mają na celu zachowanie przez jakiś czas zmarłego w łonie grupy, przynajmniej w sposób symboliczny. Wyrazem tego jest uroczysty pogrzeb z udziałem bliskich i przyjaciół, którzy niegdyś pomagali również przy toalecie zmarłego, czuwali przy zwłokach, byli obecni przy składaniu do trumny [...] a następnie przy pochówku" (J. Ru ffi é, dz. cyt., s. 294).

${ }^{22}$ Marzena Zdanowska, omawiając $\mathrm{w}$ jednym ze swoich tekstów rozmaite zbieżności pomiędzy światem ludzi i zwierząt, zwraca uwagę na ten właśnie problem: „Obszarem uznawanym zawsze za wyjątkowy dla ludzi była transcendencja, dopuszczanie istnienia tego, co wykracza poza nasze ziemskie życie. Dowodem takiego rodzaju myślenia wśród najstarszych ludzkich kultur miały być m.in. pochówki, nagrobki i kult przodków. Czy do podobnych wniosków powinno nas doprowadzić obserwowanie słoni, które nakrywają ciało zmarłego krewnego gałęziami i ziemią? 
znaleźć można wyraźne sygnały, iż pochówek - traktowany powyżej wyłącznie jako uwarunkowany kulturowo - skrywa w istocie wiele innych poziomów, których nie da się sprowadzić do kategorii rytuału:

Często ocalony pada na kolana przed zabójcą i błaga go: powiedz, gdzie wyrzuciliście ciało. Matki, ojca. To dla bliskich jest ważne. Umarłych trzeba pochować. Ktoś, kto zabił i nie chce powiedzieć, co zrobił z ciałem, pokazuje nam, że nie ma w nim żalu za zbrodnię. Wciąż nosi w sobie ideologię morderców. Może zrobić to jeszcze raz. Choćby ze strachu, że ktoś go wyda na gacaca [rodzaj lokalnego sądu oddolnego, pozwalający na wydawanie licznych wyroków bez udziału zawodowych prawników - przyp. M. Z.]. Uprzedza atak i zabija ocalonego świadka. Może, jak niedawno zdarzyło się pod Butare, wydłubać ofierze oczy, obciąć język. Komunikat jest dla nas jasny: uważajcie, my, Interhamwe [bojówki Hutu - przyp. M. Z.], wciąż tutaj jesteśmy. Milcz$\mathrm{cie}^{23}$.

Pogrzeb jest tu nie tylko prostym aktem warunkującym kulturową ciągłość danej społeczności ${ }^{24}$, lecz przede wszystkim polem mentalnego ścierania się ofiar i katów, a niekiedy nawet narzędziem autoterapii:

- Dobrze, że odwiedziłem Gikondo - mówi do mnie na lotnisku w Kigali. - Dopiero teraz wszystkich ich pogrzebałem. Tu, gdzie powinni być pogrzebani. Nie we mnie. Ale w ziemi. Wracam lekki, świeży ${ }^{25}$.

Widoczny powyżej problem relacji pomiędzy światem żywych i zmarłych jest kluczowym tematem tekstów Tochmana. Ludobójstwo, charakteryzujące się nie tylko masowością zadawanej śmierci, lecz będące także próbą fundamentalnego

[...] Jeśli dodamy do wysoko rozwiniętej emocjonalności i relacyjności słoni ich niewiarygodną pamięć, całkiem prawdopodobna staje się teza wysuwana przez niektórych badaczy o istniejącej wśród zwierząt świadomości śmierci. [...] widok martwego słonia wyraźnie niepokoi pozostałe osobniki, które stają się ciche i spięte, a do ciała podchodzą powoli. Nawet same kości wzbudzają w nich niespotykane wśród innych zwierząt reakcje. Słonie [...] dotykając szczęki, czyli części ciała dotykanej przy powitaniach, badają, czy są to kości krewnych" (M. Z d a no w s ka, Nieznośna hierarchia bytów, „Znak” nr 694 (3/2013), s. 32).

${ }^{23}$ W. Toc hman, Dzisiaj..., s. 67.

${ }^{24} \mathrm{Na}$ temat konsekwencji, jakie dla społeczności przynosi brak zmarłego, a w rezultacie niemożność rytualnego oswojenia faktu jego odejścia, pisze Thomas: „Umieranie w oddaleniu uważane jest często w społeczeństwach archaicznych za najgorszą ze śmierci dla umierającego i jego bliskich. Dla tego, który umiera - gdyż nie będzie miał prawa do ceremonii pogrzebowych, na jakie zasługuje. Ale także dla potomnych, albowiem grupa czuje się wówczas strasznie okaleczona, tym bardziej że nie może wypytać nieboszczyka o przyczyny śmierci i dlatego zakłócony zgonem porządek trudno będzie przywrócić. Zresztą, a jest to prawo uniwersalne, choć obecność trupa niepokoi jako symbol utraty, nietrwałości życia ludzkiego i nieuniknionego rozkładu, jest ona także uspokajająca: nieboszczyk jest rozpoznany przez swoich (trup oszpecony jest w pewnej mierze trupem nieobecnym), a pewność jego śmierci znosi się lepiej niż niepewność, towarzyszącą jego nieobecności i milczeniu" (L. V. Tho ma s, Trup..., s. 44).

${ }^{25}$ W. Tochman, Dzisiaj..., s. 118. 
naruszenia ludzkiej indywidualności ${ }^{26}$, upokorzenia podmiotu ${ }^{27}$ oraz całkowitego wymazania danej grupy z pamięci potomnych ${ }^{28}$, jest źródłem kulturowo-mentalnej destabilizacji, uniemożliwiającej rozliczenie z przeszłością i nakierowanie się na przyszłość. Thomas słusznie stwierdza, iż to „właśnie poprzez obrzędy pogrzebowe zmarły nie przestaje umierać. Żywi nie są już więc całkiem po stronie życia, aby nieboszczyk nie był całkowicie po stronie śmierci”29.

To właśnie sugerowany powyżej relacyjny charakter śmierci, zgodnie z którym jest ona nie tyle końcem życia, co „rozłąką z tym, kogo kochamy”30, wskazuje, iż najbardziej zasadną metodą jej ujmowania jest podejmowana przez Tochmana strategia opisu skutków, jakie wywiera na tych, którzy zostali ocaleni oraz na tych, którzy dopuścili się zbrodni. Taki model myślenia doskonale wpisuje się w fundamentalne rozróżnienie Vladimira Jankélévitcha, który różne aspekty relacji między człowiekiem a śmiercią wyprowadza z kategorii gramatycznych:

${ }^{26}$ Pisał o tym m.in. Edgar Morin: „Idea śmierci, w ścisłym sensie tego słowa, jest ideą beztreściową, czyli, jak kto chce, taką, której treść jest nieskończoną pustką. Jest to najbardziej pusta ze wszystkich pustych idei, skoro jej treść jest czymś nie do pomyślenia, nie do zgłębienia, jakimś pojęciowym «nie wiadomo czym», któremu odpowiada trupie «nie wiadomo co» [...]. Kompleks utraty indywidualności jest zatem kompleksem traumatycznym, który rządzi wszelkimi zaburzeniami wywołanymi przez śmierć i który w tym dziele nazwiemy «traumą śmierci»" (E. Morin, dz. cyt., s. 86). W tekście Morina mowa o śmierci w rozumieniu bardzo szerokim, dlatego warto dodać, że problem indywidualności staje się szczególnie istotny właśnie w przypadku ludobójstwa. Pisał o tym Theodor Adorno w kontekście Holocaustu: „Administracyjny mord na milionach sprawił, że śmierć stała się czymś, czego jeszcze nigdy w taki sposób się nie obawiano. Nie jest już możliwe, aby śmierć pojawiła się w empirycznym życiu jednostek, jako coś zgadzającego się z jego przebiegiem. Indywiduum zostało wywłaszczone z tego, co było jego ostatnią i najbiedniejszą własnością" (Th. W. Ad orno, Dialektyka negatywna, przeł. K. Krzemieniowa, Warszawa 1986, s. 508). Analizując myśl Adorna, Scherer zauważa, iż „proces historyczny zainicjowany przez zakorzenioną w potrzebie zachowania samego siebie mentalność instrumentalną nastawioną na panowanie, znajduje swą ostateczną realizację w tym, że totalne zrównanie i totalna administracja, absolutna obojętność wobec jednostki i śmierć, stają się ze sobą zbieżne: tak właśnie umierano w Auschwitz, takie też jest umieranie w naszych czasach. Zdaniem Adorno, w Auschwitz «nie umierała już jednostka [...], lecz egzemplarz»” (G. S c her e r, dz. cyt., s. 29).

27 „Bywają i tacy, którzy czują, że nie dość nas upokorzyli: otwierają groby ofiar. Wyjmują kości naszych bliskich. Zabawiają się nimi. Mieszają je z kośćmi zwierząt (W. Toc hman, Dzisiaj..., s. 68).

${ }^{28}$ Zagadnienie ludobójstwa jako „wymazywania” danej społeczności z pamięci jest wyraźnie obecne w tekstach Tochmana: „Przed wjazdem do kościoła - betonowy sześcian z namalowanym napisem: 11400 ofiar ludobójstwa - 17 kwietnia 1994. Taką informację widziałem tu piętnaście lat później. Ale po kolejnym roku już nie. Sześcian ostatnio odnowiono, odmalowano na biało. Liczba ofiar i data ich śmierci zostały pod gęstą farbą. Teraz wykaligrafowano tu jedynie jakiś antyludobójczy slogan. Na fioletowo. Jakieś never again. Tyle. Jakby ktoś chciał spełnić tamten zamiar sprawców: wymazać" (W. To ch man, Dzisiaj..., s. 74).

${ }^{29}$ L. V. Thom as, Trup..., s. 7.

${ }^{30}$ F. Wiplinger, Der personal verstandene Tod, München-Freiburg 1970, s. 45 (podaję za: G. S c he re r, dz. cyt., s. 65). Więcej na ten temat zob.: G. S che re r, dz. cyt., s. 65, przyp. 58. 
[...] śmierć w trzeciej osobie liczby pojedynczej, śmierć byle kogo, nagły zgon przechodnia z powodu, powiedzmy, zawału... Śmierć nie kryjąca w sobie żadnej tajemnicy [...]. Co się tyczy śmierci w pierwszej osobie, mojej śmierci, nie mogę o niej mówić, właśnie dlatego, że jest to moja śmierć. Zabiorę swój sekret - jeśli jest jakiś sekret - do grobu. Pozostaje śmierć w drugiej osobie, śmierć kogoś bliskiego. Oto uprzywilejowane doświadczenie filozoficzne. Przypomina moją śmierć, a jednak nie jest moją śmiercią, nie jest też bezosobową i anonimową śmiercią, którą interesuje się demografia czy medycyna. Umiera inny człowiek, a więc ja go przeżyję. Mogę zobaczyć, jak umiera. Mogę go ujrzeć martwym. To ktoś inny niż ja, ale jednocześnie jego śmierć dotyka mnie bezpośrednio ${ }^{31}$.

Bazując na zaproponowanym powyżej potrójnym modelu relacyjnym, można wskazać na wieloznaczność każdej z opisywanych w tekstach Tochmana śmierci. Ujęcie trzecioosobowe wyjaśniałoby relację pomiędzy katem a ofiarą, w którym „,mord jest nie tylko spełnieniem pragnienia zabójstwa, pragnieniem zabójstwa tout court, lecz również spełnieniem zabójstwa człowieka, tj. potwierdzeniem siebie przez zniszczenie kogoś [...]. W przypadku granicznym absolutne potwierdzenie własnej indywidualności wymaga absolutnego zniszczenia innych"32. Osoba, której odbiera się życie, jest tu traktowana na sposób przedmiotowy, będąc jedynie instrumentem wzmocnienia podmiotu ${ }^{33}$.

Śmierć pierwszoosobowa w ujęciu Jankélévitcha to proste przedłużenie koncepcji Epikura, który wykazywał, iż

śmierć [...] wcale nas nie dotyczy, bo gdy my istniejemy, śmierć jest nieobecna, a gdy tylko śmierć się pojawi, wtedy nas już nie ma. Wobec tego śmierć nie ma żadnego związku ani z żywymi, ani z umarłymi; tamtych nie dotyczy, a ci już nie istnieją ${ }^{34}$.

${ }^{31}$ V. J an kélévitch, To, co nieuchronne, przeł. M. Kwaterko, Warszawa 2005, s. 16.

${ }^{32}$ E. Morin, dz. cyt., s. 117.

${ }^{33}$ Przywodzi to na myśl wierzenia leżące u podstaw zjawiska antropofagii w wydaniu rytualnym, którą cytowany już L. V. Thomas określa mianem endoantropofagii - a więc asymilacji przez inkorporację (zob. L. V. Thom as, Trup..., s. 164-165). Kanibalizm sensu stricte nie jest zresztą u Tochmana nieobecny: „Trzeba się jakoś pocieszać: matka Leonarda nie doświadczyła najgorszego. Nie musiała - to już wiemy - jak inne matki patrzeć na śmierć swoich dzieci. Ale i te, które musiały, nie miały najgorzej. Tak ludzie w Rwandzie mówią. Bo było i tak, że zmuszano kobiety do zabijania tych, które urodziły. One też nie miały najgorzej. Bo zdarzało się i tak, że rodziły na bagnach, a potem kazano im zjadać martwe ciała swych dzieci” (W. Toch m a n, $D z i-$ siaj..., s. 140). W przypisie do tego fragmentu autor przywołuje także fragment eseju Veronique N aho u m-Grappe zatytułowanego Gwałt jako broń wojenna: „W Bośni rodzina uciekająca ze Srebrenicy w lipcu 1995 roku poświadczyła przypadek starca zmuszanego do zjedzenia wątroby własnego wnuka. Chodziło tam o innego rodzaju zerwanie więzi, kiedy to krewny w linii wstępnej musi pożreć tego, którego pośrednio spłodził, zmuszając go niejako do powrotu do stanu sprzed zapłodnienia. Zbrodnia przeciw więzom krwi nie ma prowadzić do śmierci wroga, lecz do tego, by wróg nigdy się nie narodził" (podaję za: tamże, s. 140, przyp. 1).

${ }^{34}$ Podaję za: D. L a e rti o s, Żywoty i poglqdy stynnych filozofów, przeł. K. Leśniak, Warszawa 1968, X 125, s. 645. 
Być może w tym właśnie należałoby upatrywać zasadniczej nieadekwatności pisania o śmierci w ujęciu pierwszoosobowym, znajdującej u Tochmana wyraz w nagminnej nieobecności samego procesu umierania:

- Liczyłam jego kroki, kiedy mi go wyrwali - mówi dalej Zineta. - Jeden krok, drugi, dziesiąty, coraz dalej ode mnie. Krzyczałam, odwrócił się. Dwudziesty krok, trzydziesty, już był prawie przy tej fabrycznej hali. Tam go czetnicy zatrzymali, torbę kazali rzucić na bok. Sterta walizek była wysoka chyba aż na dwa piętra. Kiram spojrzał jeszcze na nas. Wszedł do hali.

Tamtego dnia w Potoczarach upał był nie do zniesienia, ludzie nie mieli co pić35.

W powyższym fragmencie doszło do wyłączenia śmierci poza nawias dyskursu: akt morderstwa pozostaje w sferze domysłu czytelnika. Niekiedy zdarza się nawet Tochmanowi łączyć opis tego, co następowało przed śmiercią, bezpośrednio z tym, co zdarzyło się po niej:

Ale jest i druga wersja śmierci Edvina. Inni świadkowie widzieli go w Omarskiej. Widzieli, jak był torturowany na oczach siostry. Widzieli, jak 16 czerwca jego zwłoki wrzucono na żółtą ciężarówkę ${ }^{36}$.

Podobna strategia ujawnia się także w innym fragmencie:

Kilka dni później ich serbscy sąsiedzi (pierwszy dom od urzędu) postanowili zrobić miejsce serbskim tułaczom (dzisiejszym lokatorom). Wyprowadzili Husa i Sabirę za miasto.

Ich ciała ekshumowano w 1997 roku (jeszcze dwóch wujów, ich żony, ich synów) ${ }^{37}$.

Niekiedy ta eliptyczna strategia wyłączenia samego momentu śmierci poza jej opis ujęta jest w mniej surowej, a bardziej literackiej formie:

- Jedź z nami - prosiła męża.

- Kto będzie tu leczył zwierzęta, kiedy mnie zabraknie? - zapytał. - Zostanę, wszystkiego przypilnuję. Uspokoi się, to wrócicie.

Akurat dzisiaj mija osiem lat od dnia, kiedy Hasan tak do niej mówił.

Uspokoiło się.

Mubina zaczyna powrotną podró $\dot{z}^{38}$.

We wszystkich przywoływanych powyżej fragmentach tekstu śmierć jako taka znajduje się w sferze domysłu, wymagając od odbiorcy dalece posuniętej - by użyć terminu Romana Ingardena - konkretyzacji, w wyniku której z serii nieprecyzyjnych sugestii można wnioskować o konkretach. Jeśli zaś owe kon-

\footnotetext{
${ }^{35}$ W. Toch man, Jakbyś..., s. 32.

${ }^{36}$ Tamże, s. 18.

37 Tamże, s. 65.

38 Tamże, s. 27.
} 
krety - akty morderstwa - są podane explicite, to najczęściej w surowej, skondensowanej i ascetycznej formie: „Wojna i koniec wojny: obozy koncentracyjne, masowe egzekucje, masowe groby, masowe ekshumacje. Identyfikacja"39. Większość tego typu krótkich przebłysków jest tyleż dosadna, co oszczędna w środkach: „Zabijanie, mycie ścian z krwi, zakopywanie - to wymaga czasu”40. Nawet jeśli konkretom poświęcona jest w tekście nieco większa przestrzeń, to jednak ich poziom kondensacji trudny jest do zlekceważenia:

Badanie DNA jest z pewnością czymś nowym w historii wojen. Tak jak body bags, komputery, Internet, skomputeryzowane chłodnie, wózki widłowe, brytfanny na kółkach. Poza tym wszystko już było: obozy, baraki, selekcje, getta, kryjówki, ukrywanie prześladowanych, opaski na rękawach, sterty butów po zgładzonych, głód, szaber, pukanie do drzwi w nocy, zniknięcia sprzed domu, krew na ścianach, palenie domostw, palenie stodół z ludźmi w środku, pacyfikacje wsi, oblężone miasta, żywe tarcze, gwałty na kobietach wroga, zabijanie inteligencji w pierwszej kolejności, kolumny tułaczy, masowe egzekucje, masowe groby, ekshumacje masowych grobów, międzynarodowe trybunały, zaginieni bez wieści ${ }^{41}$.

Oszczędność zdaje się być jedną z głównych cech stylu Tochmana piszącego bezpośrednio o śmierci w ujęciu pierwszoosobowym. Jest ona widoczna nie tylko w przytoczonych powyżej fragmentach syntetycznych i anonimowych, lecz nawet tych, które zakładają indywidualność ofiar:

Thierry Ishimwe, dziewięć miesięcy. Na zdjęciu leży na kwiecistym prześcieradle. Ścięta maczetą w ramionach matki.

Françoise Murengezi Ingtabire, dwanaście lat [...]. Ścięta.

Bernardin Kambanda, siedemnaście lat [...]. Maczeta.

David Mugiraneza, dziesięć lat [...]. Zamęczony na śmierć.

Fidele Ingabire, dziewięć lat (jak Leonard). Strzał w głowę.

Ariane Umutoni, cztery lata (jak brat Leonarda). Nóż w oczy.

Fillette Uwase, dwa lata. Rozbita o ścianę.

Dzieci, zanim ginęły, musiały patrzeć, jak gwałcono ich matki (wnuczęta - jak gwałcono ich babcie). Mężowie patrzyli, jak gwałcono ich żony (dziadkowie - jak wnuczki). I jak wkładano im między nogi butelki. Tak najczęściej zabijano kobiety Tutsi: ciosem w brzuch i poniżej. Nim skonały, patrzyły na śmierć swoich dzieci. I ojcowie te $\dot{z}^{42}$.

Oczywiście w obydwu analizowanych tekstach można znaleźć takie fragmenty, które wymykają się powyższym twierdzeniom, warto jednak pamiętać, że ich liczba jest niewielka. Pierwszy tradycyjny opis śmierci w książce Jakbyś kamień jadła pojawia się dopiero na stronie czterdziestej ósmej, a na dodatek dotyczy nie

\footnotetext{
39 W. Toc hma n, Jakbyś..., s. 14.

40 Tamże, s. 20.

41 Tamże, s. 25.

42 W. Tochman, Dzisiaj..., s. 13-14.
} 
tyle morderstwa, co samobójstwa jednego z bohaterów ${ }^{43}$. Zdecydownie bogatszy jest pod tym względem reportaż Dzisiaj narysujemy śmierć i w tym upatrywać należy podstawowej różnicy pomiędzy analizowanymi utworami.

Powyższe zastrzeżenia nie zmieniają faktu, iż w obydwu tekstach fundamentalny nacisk postawiono na zagadnienie śmierci drugoosobowej, z perspektywy której odejście drugiego człowieka jawi się jako śmierć tego, kto po nim zostaje ${ }^{44}$. Zdaniem Gabriela Marcela „śmierć drugiej osoby może nas tak dotknąć i nami wstrząsnąć, że jej konsekwencją będzie «tragedia dalszego życia». Pojawia się ona wtedy, gdy w przypadku śmierci drugiego człowieka mówimy: «Jego śmierć jest moją śmiercią»" ${ }^{45}$. Czytając reportaże Tochmana, można odnieść wrażenie, iż to właśnie śmierć drugoosobowa stanowi oś refleksji nad ludobójstwem oraz opisem świata, który po nim następuje ${ }^{46}$ :

Powiem jak każdy psychiatra: człowieka tworzą więzi. Człowiek karmi się relacją z drugim człowiekiem. Ale pokarmu nie ma. Wszystko, co bliskie, zostało unicestwione. Nie ma drugiego

${ }^{43}$ Przytaczam fragment w całości:

„,- Obiecaliśmy sobie, że żaden z nas nie da się wziąć żywcem. Wiesz, co Serby robili z naszymi?

- Wiem - mówi Mubina.

- Krzyżowali...

- Wiem.

- Pierwszego dnia szliśmy bez kłopotów, ale powoli. I Hasan szedł z nami. Drugiego dnia, gdzieś nad Kravicą, wpadliśmy w serbską zasadzkę. Chłopaki wariowali, wkładali sobie granaty w usta. Huk, raz-dwa, masakra straszna. Hasan, inaczej niż wszyscy, przyłożył sobie granat do brzucha. Skulił się, o tak, i już”.

[W. Toch man, Jakbyś..., s. 48].

Pierwszy tradycyjny opis aktu morderstwa pojawia się dopiero na stronie 60 tekstu.

${ }^{44}$ Pisał na ten temat już św. Augustyn, medytując nad śmiercią bliskiego mu przyjaciela: „moja i jego dusza były jedną duszą w dwóch ciałach” [Św. A u gu st y n, Wyznania, IV, 6, przeł. Zygmunt Kubiak, Kraków 2007, s. 99-100].

45 Za: Scherer, s. 60.

${ }^{46}$ Ciekawe jest, iż u Tochmana świat po ludobójstwie jawi się często jako postapokaliptyczny - śmierć tysięcy ludzi staje się śmiercią całej rzeczywistości, co byłoby zgodne z ujęciem Marcela. Książka Jakbyś kamień jadła zaczyna się wręcz od swoiście postapokaliptycznego opisu:

„Był ostatni dzień roku [...]. Nim nastał zmierzch, zdążyliśmy zobaczyć wioski, w których nikt już nie mieszkał. Domy i świątynie zrównano z ziemią. Co zrobiono z ludźmi?

Jechaliśmy przez Mostar, ale go nie widzieliśmy. Miasto jak las: niby coś miga za ciemnym oknem, ale nie wiadomo co to [...] Był mróz.

[...] Mówił, że kiedy to wszystko się skończy, a on wciąż będzie żył, ucieknie gdzieś w świat, bo tu już życia nie będzie”.

[W. Toc h m a n, Jakbyś..., s. 9].

Odwołanie do apokalipsy można znaleźć także w książce Dzisiaj narysujemy śmierć: „Potem była pierwsza wojna światowa i Rwanda przeszła pod panowanie Belgów. Po krótkim rozeznaniu sytuacji Belgowie zobaczyli to, za co Rwanda zapłaci apokalipsą kilkadziesiąt lat później” (W. To c h man, Dzisiaj..., s. 26). Problem jest również obecny w innych tekstach autora, m.in. w reportażu Amen: „Niektórym tamtego ranka świat się skończył” [W. Toc h m a n, Amen..., s. 195]. 
ciała, na którym można by się oprzeć. Nie ma kogo objąć. I nikt mnie nie obejmie. Nie można objąć siebie samego ${ }^{47}$.

I rzeczywiście, trudno porównywać którykolwiek z cytowanych wcześniej fragmentów z tymi, które dotyczą konsekwencji śmierci dla osób pozostałych przy życiu. Temat ten przyjmuje u Tochmana rozmaite formy, najczęściej opierając się na relacji pomiędzy ofiarą a jej bliskim:

Zgwałcili mnie, jak tylko mogli. Tutaj, w domu. Ale zwlokłam się i wyszłam przed drzwi, żeby zobaczyć, co z dziećmi. Pierwszy miał dwadzieścia lat, drugi - dziewięć, córka - sześć. Starszemu dali gruby kij i kazali bić młodszego. Córce kazali patrzeć. I ja patrzyłam. Syn nie podniósł ręki na brata, spuścił głowę, dostał motyką w kark. Upadł na młodszego. Mój drugi synek dostał motyką w czoło. Nie płakałam. Nie bałam się ${ }^{48}$.

Niekiedy akcent stawia się na konsekwencjach partycypacji w akcie zabijania:

Dokończę za ciebie, Balancila. Starsze nacinali, żeby konały powoli. Wszystko działo się na waszych oczach. Kazali wam grzebać ciała waszych dzieci. Ale one wciąż żyły. Błagałyście, już sam nie wiem o co. W końcu wrzucili te wszystkie maleństwa do latryny obok domu. Dwanaścioro. Krzyczały. Wy umilkłyście. Adela do dzisiaj milczy. Tak było, Balancila? ${ }^{49}$

Zdarza się nawet, że w diadę zabity-bliski włącza się także sam zbrodniarz:

Zabili ojca, wszystkich moich zabili. Niedaleko, Wiem kto. Mieszka obok i dzisiaj. Siedział w więzieniu. Wrócił na Gikondo. Powiedział mi na powitanie, że ładnie wydoroślałem. Że jestem podobny do ojca. A teraz głaszcze moją córkę po głowie. Powtarza, że to wypisz wymaluj babcia. Moja mama, której uciął głowę ${ }^{50}$.

Wszystkie te skomplikowane sieci relacji między martwym ukochanym, żywym zbrodniarzem i rozerwanym mentalnie podmiotem uwidaczniają się u Tochmana na każdym kroku, podobnie jak trauma związana z sytuacjami granicznymi:

Niejedna potknęła się o trupa męża [...].

Drugi dzień przyszedł, trzeci, czwarty. Siedziałyśmy głodne w domach. Brudne, bez wody. Upał nie do zniesienia. Na ciałach naszych mężów pasły się muchy.

Nie pozwalali nam wyjść z domu, pochować zabitych.

Trupy śmierdziały ${ }^{51}$.

\footnotetext{
${ }^{47}$ W. Toc hma n, Dzisiaj..., s. 47.

48 Tamże, s. 46.

49 Tamże, s. 70.

${ }^{50}$ Tamże, s. 10.

${ }^{51}$ W. To c h m a n, Jakbyś..., s. 102.
} 
Wbrew pozorom, często te najbardziej traumatyczne doświadczenia nie dotyczą wcale relacji, jaka wywiązuje się bezpośrednio pomiędzy ocalonym a mordercą, lecz pomiędzy ocalonym a jego zmarłym bliskim:

- Ścięli nas wszystkich - usłyszeli wreszcie. - Sąsiedzi. Mamę, tatę, braci też, i siostry. Było nas dziesięcioro. Jeszcze babcię, ciotkę i jej dzieci, wszystkich ośmioro. Leżałem pod nimi chyba tydzien. Bez ruchu, powietrza, wody. Piłem sok, który z nich wypływał ${ }^{52}$.

Oczywiście nie sposób jednak pominąć szeregu związków bezpośrednich pomiędzy zbrodniarzem a ofiarą, która nie została zabita, lecz okaleczona. Mowa tu przede wszystkim o gwałtach ${ }^{53}$ :

Wyobraźmy sobie ciało zgwałcone przez dziesiątki mężczyzn z maczetami w rękach. W tym strzępie jeszcze krew pulsuje, lepi się na kikutach. Bo ciału obcięli ręce, które próbowały chronić podbrzusze. Co taka kobieta, jeśli cudem ocalała, myśli o swoim ciele? Że dzięki niemu mordercy nie zabili jej od razu. Że uratowała ją pochwa, że tylko dzięki pochwie żyje. Jest przedmiotem. Wiadrem na spermę ${ }^{54}$.

${ }_{52}$ W. Toch man, Dzisiaj..., s. 24.

${ }_{53}$ Problem gwałtu wojennego jako instrumentu opresji oraz jego fizycznych i psychicznych konsekwencji dla ofiary zasługuje na osobne omówienie i w tym miejscu można go jedynie wyraźnie zasygnalizować. Warto natomiast wspomnieć, iż zdaniem wielu badaczy problem seksu i śmierci jest praktycznie nierozłączny. Ruffié zauważa, że już „od dawna ludzie zdawali sobie sprawę ze związku istniejącego między dwoma zjawiskami, które były uosobione w Panteonie greckim w postaciach Erosa i Tanatosa. Zresztą liczne koncepcje mityczne, które znalazły wyraz w spekulacjach gnostycznych i chrześcijańskich w pierwszych wiekach naszej ery, widziały ścisły związek między śmiercią a życiem płciowym, a co za tym idzie między abstynencją a nieśmiertelnością" (J. Ruffié, dz. cyt., s. 292). Problem owej dialektycznej relacji jest u Tochmana bezpośrednio obecny: „Gwałcili mnie długo i brutalnie. Moje dzieci musiały na to patrzeć. Ale i tak nie miały najgorzej. Bo inne były zmuszane do trzymania nóg matki tak, aby morderca miał do niej łatwiejszy dostęp. I one nie miały najgorzej. Bo zdarzało się u nas i tak, że dorastający chłopcy na rozkaz morderców gwałcili swoje matki. Ścinali syna, kiedy penetrował ciało tej, która dała mu życie" (W. Tochman, Dzisiaj..., s. 60). Jednak problem relacji pomiędzy śmiercią i życiem płciowym ma także inny aspekt. Jak pisze Thomas, ,powrót do Ziemi-Matki, z perspektywą odrodzenia się w łonie kobiety należącej do tego samego rodu, nadaje śmierci ambiwalentny wydźwięk: owszem, wchodzi tu w grę strach, rozstanie, ale także ufność, spokój wewnętrzny; śmierć i narodziny są bowiem odwrotnymi stronami tego samego przejścia z jednego świata do drugiego. Możemy tu dodać, że już w czasach prehistorycznych zwłoki bywały grzebane w pozycji płodu, w niszach pieczar, co potwierdza macierzyńską konotację śmierci. Mówiąc językiem psychoanalizy: śmierć macierzyńska wywodzi się z instynktowego id: powrót podczas wiecznego spoczynku do matki, poczucie bezpieczeństwa, ale również rozłąka z matką, osamotnienie i niepokój” (L. V. Tho mas, Tworzenie tanatologii, przeł. M. L. Kalinowski [w:] red. S. Rosiek, Wymiary śmierci, Gdańsk 2010, s. 23). W kontekście powyższej wypowiedzi znamienny zdaje się fragment jednej z analizowanych książek: „Dzień po dniu, tydzień po tygodniu, z pomocą bakterii, robactwa, większych zwierząt i deszczy, ziemia cierpliwie i konsekwentnie wchłaniała martwych w siebie. I ziemia teraz o ciałach przypomina. Niepokoi, dręczy. Ruszysz motyką, a ona cię oskarża. Ziemia - sumienie. Ziemia - mroczne archiwum, baza danych, twardy dysk. Ziemia - prokurator. Wszędzie kości. Sterczą. Turlają się czaszki. Jednakowo pęknięte" (W. To c h m an, Dzisiaj..., s. 77).

${ }^{54}$ Tamże, s. 44. 
Przytoczone wyżej fragmenty obydwu książek rażą swoją werystyczną brutalnością, jednak należy zauważyć, iż najbardziej poszkodowanym jest w nich nie trup, lecz ocalony: matka patrząca na śmierć własnych dzieci, rodzice grzebiący swe pociechy żywcem, syn znoszący bliskość mordercy własnych rodziców, żony potykające się o trupy mężów i duszące się od ich zapachu, syn żywiący się sokiem wypływającym z ciał krewnych, wreszcie - okaleczona, brutalnie zgwałcona kobieta. Warto zresztą zauważyć, że autor w obydwu przypadkach zajmuje się zbrodniami ludobójstwa na wiele lat po ich zakończeniu, niejako programowo zakładając badanie pracy pamięci u ofiar, piętna, jakie na nich ciąży oraz relacji, $\mathrm{z}$ jakich nie są w stanie się wyplątać. Założeniem wyjściowym nie jest więc ustalanie faktów na temat samych zdarzeń, lecz przede wszystkim ukazanie ich konsekwencji psychicznych i społecznych. Trupy są więc u Tochmana traktowane w sposób swoiście przedmiotowy, będąc raczej przyczyną dotkliwego cierpienia żywych, aniżeli signifiantem cierpienia samego w sobie. Jak wykazano powyżej, jest to wyraźnie widoczne w warstwie wspomnień ocalałych oraz konsekwencji psychicznych, jakie one niosą. Jednak nie sposób ograniczyć problemu wyłącznie do tego niematerialnego wymiaru. Częsta nieobecność ciał zmarłych prowokuje liczne zachowania kompensacyjne, które przejawiają się przede wszystkim w relacjach pomiędzy żywymi a ubraniami bądź kośćmi zmarłych:

Nad innymi strzępami pochyla się siwa pani w granatowym kostiumie. Od rana stoi nad jednym i tym samym ubraniem. Układa je, jakby chciała, by ładnie się prezentowało. Poprawia ciemne spodnie, jasną koszulę i coś, co było swetrem w kolorze bordo. Głaszcze to wszystko, jak głaszcze się człowieka [...].

Siwa pani w granatowym kostiumie, którą widzieliśmy tu wcześniej, zostawia na chwilę upatrzone ubrania bez opieki [...].

Matka pochyla się i poprawia nogawkę. Podnosi się i ocenia, czy na pewno wszystko dobrze się prezentuje.

- To Edvin - mówi, jakby nam kogoś przedstawiała. - Mój syn ${ }^{55}$.

Podobny sposób myślenia widoczny jest także w innych miejscach obydwu książek:

Teraz razem z ziemniakami kości kopię. Czy to mój? Czy mój brat, który akurat dwa dni wcześniej zjechał z Niemiec na urlop? Wszędzie kości sterczą, pływają w studniach ${ }^{56}$.

Widoczne powyżej strategie obchodzenia się ze zmarłym są charakterystyczne dla sytuacji, gdy jego ciało nie zostało odnalezione. Pisze o tym przywoływany już Thomas:

\footnotetext{
${ }^{55}$ W. Toch h a n, Jakbyś..., s. 13, 16, 17.

56 Tamże, s. 101.
} 
Skoro nie ma nic tragiczniejszego niż brak trupa, podwójnie nieobecnego - bo nieobecnego wśród żywych i wśród zmarłych - należy temu zaradzić: stąd praktyka substytutów, które stanowią kontynuację fikcyjnych ceremonii pogrzebowych. Substytuty mogą być rozmaitej natury, zależnie od tego, czy wynikają z magii kontaktowej, zasad metonimicznych czy symbolicznego zastępstwa $^{57}$.

W świetle proponowanego tu rozróżnienia, ubrania należałoby przyporządkować do kategorii symbolicznego zastępstwa („to Edvin, mój syn”), zaś kości - do myślenia metonimicznego (,czy to mój brat?”). Obydwa przypadki sprowadzają się do ogólnej zasady, w której „,chodzi o to, by za pomocą metonimicznych lub metaforycznych figur zastąpić trupa, którego nie ma; chodzi o substytucję jego gnicia obrazem uspokajającym, o dostarczenie nieboszczykowi solidnego punktu oparcia, w którym będzie mógł zamieszkać lub który go będzie przyzywać, o uwiecznienie jego wspomnienia" ${ }^{58}$.

By nie wchodzić jednak w szczegółowe antropologiczne dystynkcje, wystarczy w tym miejscu ograniczyć się do spostrzeżenia, iż źródłem cierpienia ocalonych po ludobójstwie - a to właśnie okazuje się głównym przedmiotem zainteresowań Tochmana - są nie tylko traumatyczne wspomnienia, lecz także teraźniejsza przestrzeń, której przeszłe piętno (,Tu, gdzie teraz stoimy, nie mogłaby wtedy stać. Snajper trafiłby ją w mózg" ${ }^{\text {"59) }}$ ) paraliżuje społeczność w specyficznie rozumianym bezczasie ${ }^{60}$. Trupy są więc u Tochmana nie tylko przyczyną cierpienia konkretnych ocalonych i katów, lecz także strażnikami obowiązujących relacji społecznych, sprawującymi nad nimi wieloletni dyktat: życie w Bośni i Rwandzie zdaje się być w całości podporządkowane temu, co wydarzyło się dawniej. Ofiary serbskiego terroru całą energię pożytkują na poszukiwaniu zaginionych krewnych, Serbowie budują wokół siebie okop z poczucia niespełnionej eksterminacji, Hutu obawiają się zemsty Tutsi, zaś Tutsi czekają na powtórny mord ze strony Hutu. Nastroje te sprawiają, że każde miejsce staje się miejscem pamięci, w którym warstwa symboliczna zamraża możliwość wyjścia poza posttraumatyczne relacje społeczne ${ }^{61}$.

Tochman usiłuje owe skomplikowane relacje nie tylko pojąć, ale zarazem wprowadzić w nie jakikolwiek ład. Jego praca to jednocześnie próba upamiętnie-

${ }^{57}$ L. V. Thom a s, Trup..., s. 44.

${ }^{58}$ Tamże, s. 49.

${ }^{59}$ W. Toc h man, Jakbyś..., s. 53.

${ }^{60}$ Analogiczne wnioski pojawiają się w mojej analizie książki J. Hu go-B a d er a Dzienniki kołymskie (M. Zi mno ch, Przestrzenie reportażu. O „Dziennikach kołymskich” Jacka Hugo-Badera, ,Znak” nr 688 [9/2012]).

${ }^{61}$ Ernesto De Martino słusznie zauważa, iż „doświadczeniu utraty osoby bliskiej odpowiada doświadczenie utraty świata, który jawi się jako dziwny, obojętny, mechaniczny, sztuczny, teatralny, nierzeczywisty, oniryczny, bez znaczenia, niematerialny i tym podobne" (E. De Martin o, Morte e pianto rituale nel mondo antico: dal lamento pagano al pianto di Maria, Torino 1958, s. 26 [za: A. M. di N ola, Tryumf śmierci. Antropologia żałoby, przeł. J. Kornecka, M. W. Olszańska i in., Kraków 2006, s. 186]). 
nia ofiar. Tylko w ten sposób można tłumaczyć ascetyczne fragmenty z listami ich nazwisk:

Dzieci zaginione w Nevesinju w czerwcu 1992 roku:

Szpiković - (7 dni, bez imienia),

Asim Szpiković (17 lat),

Huso Szpiković (3 lata),

Huso Aliczić (8 lat),

Meho Aliczić (17 lat),

[...]

Emin Ploskić (5 lat),

Samra Ploskić (4 lata),

Ajla Ploskić (9 miesięcy) $)^{62}$.

Podobne wyliczenia nasuwają skojarzenie z Vernantowską analizą Odysei Homera:

Odyseusz zadrżał na widok gromadzącego się jakby za progiem tłumu zmarłych, niewyraźnej masy widm, niezliczonego roju cieni, które nikim już nie są i których okropny, bezładny i niesłyszalny wrzask nie ma już w sobie nic ludzkiego.

Przywoływać zmarłych - tak jak czyni to Odyseusz, gdy pragnie rozmawiać z cieniem Tejrezjasza - to wnieść ład i liczbę w tę bezkształtną masę, odróżnić osoby, zmuszając je, by ustawiły się w rzędzie, przedstawiały się po kolei, mówiły w swoim imieniu i przypominały sobie ${ }^{63}$.

Tak Odyseusz, jak i Tochman wydają się bezradni wobec „bezkształtnej masy" widm, a jednak przywołanie zmarłych z imienia wprowadza w nią ład, dyktując światu zmarłych porządek świata żywych. W tym właśnie należałoby się doszukiwać fundamentalnej roli analizowanych tekstów, które jawią się jako próba okiełznania wypartego tematu śmierci i przywrócenia go do dyskursu. Dla niektórych próba ta może się wydawać chybiona. Jak pisze Gilles Ernst,

utwór prozatorski, będący kunsztowną formą wypowiedzi, stanowi negację śmierci jako takiej. Otóż próba wprowadzenia jej do tematu, wymówienia lub choćby zapisania jej nazwy jest - zgodnie z heglowską dialektyką - równoznaczna z częściowym jej wyeliminowaniem; coś bezkształtnego próbuje się powołać do życia właściwego pojęciu, życia w strukturze, coś, co nie daje się opowiedzieć, pragnie się zawrzeć w opowieści. Tymczasem jedynie milczenie i nieobecność tego tematu są stosownymi postawami wobec śmierci. Ale czy na pewno? Możemy wszak postawić sobie pytanie o to, czy samo milczenie nie jest jeszcze nazbyt wymowne ${ }^{64}$.

${ }^{62}$ W. To c h m a n, Jakbyś..., s. 88-89.

${ }^{63}$ J. P. Vern an t, Śmierć grecka - śmierć o dwóch obliczach, przeł. M. Sawiczewska-Lorkowska [w:] red. S. Rosiek, Wymiary..., s. 280-281.

${ }^{64}$ G. Ernst, Śmierć jako temat opowiadania: „Dianus” Georges'a Bataille’a, przeł. M. L. Kalinowski [w:] red. S. Rosiek, Wymiary..., s. 230. 
Należy jednak zaznaczyć, iż postulat Ernsta nie poddaje się jednoznacznej ocenie, a dyskusja nad sensownością choćby najbardziej ograniczających prób wyrażania rzeczy niewyrażalnych musi ustąpić twardemu spostrzeżeniu: próby te zawsze były podejmowane, a ich zaniechanie za każdym razem musi się wiązać nie tylko z odrzuceniem dorobku ludzkiej cywilizacji, ale wręcz z rezygnacją z konstytutywnego elementu samego człowieczeństwa. Próba mówienia o rzeczach wypartych i wykluczonych ze świadomości społecznej, jakkolwiek trudna by ona nie była, jest dowodem ciągłości, nie wykluczając jednak ewolucji. Rozpatrywane w ten sposób teksty Tochmana stają się nie tylko efektem prób przywrócenia tego, co odrzucone, lecz także narzędziami kształtowania nowej wrażliwości społecznej, co w świecie schematycznych obrazów i uproszczonych wyobrażeń zdaje się być szczególnie cenne.

Mateusz Zimnoch

'DEATH BROUGHT BACK':

GENOCIDE IN WOJCIECH TOCHMAN'S REPORTAGE BOOKS

Summary

The aim of this paper is to demonstrate the usefulness of the anthropological perspective for the study of literary reportage. The author begins with a brief review of the main concepts of 20thcentury anthropology and philosophy of death (L.V. Thomas, Philippe Ariés, Vladimir Jankélévitch, Gabriel Marcel). They are then made part of a critical approach, specially devised for a culturalstudies conformant readings of Wojciech Tochman's two books of literary reportage on the genocide in Bosnia, Jakbyś kamień jadła (Like Eating a Stone), and Rwanda, Dzisiaj narysujemy śmierć (Today We're Going to Draw Death). What those readings show is that a number of practices from the domain of the anthropology of savage tribes (like metaphorical and metonymical substitution of the dead, perverse sexual rituals, cannibalism) can well resurface among civilized societies. Furthermore, we can get a better understanding of what is described in the text thanks to the inclusion in our interpretive frame of some philosophical ideas (especially Jankélévitch's theory of death in three persons and Marcel's philosophy of dialogue). The approach devised and applied here is an interdisciplinary tool which combines the resources of literary criticism (as used in the study of Polish literature in the context of communication and media), anthropology and philosophy. 